\title{
IDENTIFIKASI MODAL SOSIAL PADA PROGRAM PEMBERDAYAAN MASYARAKAT MISKIN MELALUI DANA ZAKAT, INFAK DAN SEDEKAH
}

\author{
Atut Frida Agustin \\ Email: dha_eco@yahoo.com / HP: 082330185467 \\ Khusnul Ashar dan Multifiah \\ Fakultas Ekonomi Universitas Brawijaya \\ Jalan Veteran Malang 65145 Indonesia
}

\begin{abstract}
Paradigma based on this research is naturalistic paradigm sourced from phenomenologist which more criticize on positivism approach which considered to rigid, black and white, also toomuch obeying the concept. According to knowledge paradigm an social science also problem to be answered in this research, the research uses qualitative approach. The research finding are: 1) people empowerment in Sumberoto village based on Islamic religious values, they are believing, purity, and ukhuwah islamiah (Islam brotherhood). This model is also built by trust and norm (rule) in society with reciprocal relations. While system used is network, with voluntary, similarity, freedom, and civilization, moved by proactive all empowerment management. 2) moral value reflected in social capital and religious value has played role in producing poor people empowerment model more fair, independence, honorable, and continued without losing humanity. That's the poor people empowerment model which became this research's thesis.
\end{abstract}

Keywords: pemberdayaan, modal sosial, zakat, infaq, shadakah.

Salah satu bentuk modal sosial dan kearifan lokal yang bisa menjadi solusi dalam menanggulangi kemiskinan khususnya umat Islam adalah lembaga zakat, infak, dan sedekah (ZIS). Dana ZIS kalau dikelola secara baik akan memperkecil penyebab kemiskinan bahkan bisa mengentaskan kemiskinan melalui pemberdayaan masyarakat miskin. Dengan demikian dana zakat, infak dan sedekah (ZIS) bisa digunakan untuk memberi mereka (penduduk miskin) peluang kerja melalui pemberian bantuan modal atau alat produksi, bantuan pelatihan dan sebagainya. Dari bantuan tersebut mereka akan menjadi produktif, seperti yang selama ini dilakukan oleh yayasan Al-Aqsha yang ada di Desa Sumberoto Kecamatan Donomulyo Kabupaten Malang.

Dalam menjalankan aktifitasnya yayasan Al-Aqsha mendapatkan dana dari simpatisan, donatur tetap, Baitul Maal Hidayatullah, dan penduduk setempat yang mampu. Yayasan ini mempunyai empat departemen didalam program kerjanya, yaitu : (1) Departemen Pendidikan, memberikan beasiswa kepada siswa yang kurang mampu, (2) Departemen Kesehatan, khusus departemen kesehatan yayasan Al-Aqsha mendapatkan pendampingan dari BMH (Baitul Maal Hidayatullah), (3) Departemen Ekonomi, melaksanakan program pemberdayaan umat sekitar dengan memberikan pelatihan kewirausahaan, memberikan modal usaha (pertanian), pendampingan usaha 
yang sudah dilakukan masyarakat sekitar, (4) Departemen Dakwah, dakwah adalah salah tujuan utama didalam pendirian yayasan Al-Aqsha, saat ini membawahi 4 majelis dakwah (kholaqoh) yang merupakan perkumpulan pengajian masyarakat sekitar.

Khusus untuk gerakan pemberdayaan ekonomi umat sekitar selain memberikan pelatihan yayasan ini juga memberi bantuan modal usaha pertanian yang diwujudkan dalam bentuk bantuan bibit kelapa sawit. Bibit kelapa sawit merupakan bantuan langsung yang diberikan oleh LKMP5 (Lembaga Kesejahteraan Masyarakat Mandiri 5 Pengusaha) asal Kabupaten Blitar. Bantuan modal yang diberikan merupakan kumpulan zakat dari lima orang pengusaha tersebut. Khusus pemberian modal usaha pertanian, masyarakat diberi bantuan bibit kelapa sawit yang dikoordinir melalui yayasan AlAqsha. Bantuan bibit kelapa sawit yang diberikan berjumlah tujuh ratus ribu batang dan dua kali paket pupuk.

Penyaluran bibit kelapa sawit diberikan kepada enam ribu kepala keluarga, dimana masing-masing kepala keluarga rata-rata mendapatkan tujuh puluh dua batang bibit kelapa sawit. Total tanah kepala keluarga yang ditanami kelapa sawit adalah 4.200 ha, dengan rata-rata kepemilikan lahan kepala keluarga sekitar 500 meter. Sesuai dengan masa perhitungan panen, kelapa sawit biasanya dapat dipanen pada tahun ke-lima, tetapi 3,5 tahun berjalan pohon kelapa sawit sudah dapat dinikmati hasilnya oleh sebagian petani. Sekitar 600 ha lahan yang ditanami kelapa sawit sudah dapat dinikmati. Rata-rata tiap TBS (Tandan Buah Segar) dapat menghasilkan 25kg buah sawit. Dengan jumlah panen tersebut rata setiap keluarga mendapatkan penghasilan sebesar Rp. 2.400.000.

Sebelum mendapatkan bantuan modal bibit kelapa sawit, penduduk sekitar adalah petani musiman, dengan tanaman tumpang sari berupa singkong. Karena bersifat musiman dalam menanam padi, pendapatan petani berdasarkan musim tanam yang ada. Sedangkan tanaman jagung juga dapat dinikmati hasilnya satu tahun sekali. Dari hasil yang dapat dinikmati petani dalam bertanam jagung sangat kecil, dimana modal yang dikeluarkan sebesar 2 juta sedangkan hasil yang dapat terjual sekitar 2,6 juta. Pendapatan petani hanya Rp. 600.000,- tanpa dihitung biaya tenaga penggarap. Hasil beberapa penelitian seperti yang dilakukan oleh Choi (2004), Ellison, (1994), Piche (1999) Lochart (2005) dan Brigaitis (2005) menunjukkan hasil bahwa ada hubungan positif antara keberadaan lembaga keagamaan seperti majelis dakwah, pengajian dan Lembaga Amil Zakat, Infak, dan sedekah (LAZIS) dengan penguatan modal sosial masyarakat dan peningkatan kesejahteraan masyarakat miskin.

Mengacu pada uraian tersebut di atas, maka permasalahan yang bisa dimunculkan untuk mengatasi kemiskinan melalui dana ZIS adalah bagaimana keberadaan modal sosial dalam program pemberdayaan masyarakat miskin melalui dana ZIS yang dikelola oleh Yayasan Al Aqsha. Berdasarkan pada permasalahan yang dirumuskan tersebut di atas, maka tujuan yang ingin dicapai dari penelitian ini adalah mengetahui keberadaan modal sosial dalam program pemberdayaan masyarakat miskin melalui dana ZIS yang dikelola oleh Yayasan Al Aqsha.

\section{METODE}

Pendekatan yang digunakan dalam penelitian ini adalah pendekatan kualitatif. Fenomena keputusan dan tindakan kolektif masyarakat untuk mengatasi kemiskinan di sekitarnya dengan menggunakan dana ZIS merupakan keadaan yang komplek sehingga membutuhkan penjelasan dan interpretasi yang mendalam. Hal ini sejalan dengan uraian 
Ulin et. al. (2002) bahwa: "...ketika tujuan utama sebuah penelitian adalah untuk menggali dan menjelaskan perilaku ketimbang menggambarkannya, ketika masalah penelitian tidak "biasa" dan tidak mencukupi untuk diteliti, atau ketika kata-kata yang pantas untuk dikomunikasikan dengan responden tidak tersedia, maka peneliti disarankan untuk menunjukkan jawaban pertanyaan penelitiannya dengan menggunakan metode kualitatif".

Latar penelitian ini adalah berupa proses sosial yang terjadi dalam masyarakat yang divisualisasikan melalui program pemberdayaan masyarakat berdasarkan konsep Islam, melalui zakat, infaq, shadakah, dan wakaf. Obyek dari penelitian ini adalah tindakan kolektif masyarakat atau orang untuk menanggulangi kemiskinan melalui dana zakat, infaq, shadakah, dan wakaf. Sedangkan yang menjadi subyek dalam penelitian ini adalah para pelaku (orang) yang secara langsung terlibat di dalam realitas yang diamati, terutama yang berkaitan dengan persepsi, motivasi dan keuntungan/ manfaat yang diperoleh dari program tersebut. Secara spesisfik, penelitian ini dilakukan terhadap Yayasan Al-Aqsha di Desa Sumberoto, Kecamatan Donomulyo, Kabupaten Malang.

\section{HASIL DAN PEMBAHASAN}

\section{Memaknai Peran Modal Sosial dalam Program Pemberdayaan Masyarakat Miskin.} Aspek Jaringan (Net Working)

Jaringan (net working) merupakan hubungan yang saling berdampingan dan dilakukan atas prinsip kesukarelaan (voluntary), kesamaan (equality), kebebasan (freedom), dan keadaban (civility). Jaringan hubungan sosial biasanya akan diwarnai oleh suatu tipologi khas sejalan dengan karakteristik dan orientasi kelompok pada kelompok sosial yang biasanya terbentuk secara tradisional atas dasar kesamaan garis keturunan (lineage), pengalaman-pengalaman sosial turun-temurun (repeated social experineces), dan kesamaan kepercayaan pada dimensi ketuhanan (religious beliefs).

Hubungan yang saling berdampingan dan dilakukan berdasarkan prinsip di atas ditemukan dalam model pemberdayaan masyarakat miskin yang ada di Desa Sumberoto. Unsur-unsur berdampingan yang berkerja secara bersama-sama dalam model pemberdayaan tersebut antara lain: Pertama, Muzakki yang dalam hal ini tergabung dalam LKMP5 berperan sebaai penyandang dana program pemberdayaan. Kedua, Yayasan Al Aqsha berperan sebagai: (a) mediator/pencari penyandang dana; (b) perumus program; dan (c) pelaksana program. Ketiga, Kelembagaan Masjid, berperan sebagai koordinator kelompok program pemberdayaan. Keempat, Masyarakat berperan sebagai objek dan pelaku program.

Unsur-unsur diatas yang bekerjasama dalam jaringan dilandasi oleh prinsip: (a) kesukarelaan (voluntary), kesamaan (equality), kebebasan (freedom), dan keadaban (civility). Bagi setiap muslim yang mempunyai harta sampai pada nisabnya, maka wajib mengeluarkan zakatnya. LKMP5 (Lembaga Kesejahteraan Masyarakat Mandiri 5 Pengusaha) merupakan kumpulan pengusaha sukses. Dua diantaranya, Mbah Mas'oed dan Mbah Sis rutin mengeluarkan zakat maal-nya untuk membantu orang-orang sekitarnya.

Dalam pelaksanaan program pemberdayaan masyarakat miskin tersebut yayasan bekerjasama dengan pihak masjid setempat. Berdasarkan kesamaan persepsi 
untuk bersama-sama berjuang mengentaskan kemiskinan di wilayahnya ketua takmir masjid ditunjuk sebagai ketua kelompok, hal ini dimaksudkan ketua takmir lebih mudah untuk memobilisasi massa, menjadi panutan, dan yang terpenting adalah amanah dalam melaksanakan kegiatan program. Pada saat pelaksanaan program budidaya kelapa sawit, pihak yayasan tetap memberikan kesempatan kepada masyarakat untuk tetap dapat menanam singkong dan jagung disela-sela tanaman kelapa sawit. Ketua kelompok tani sawit adalah takmir masjid setempat dengan harapan ketua takmir dapat memobilisasi masa, menjadi panutan bagi masyarakat sekitar.

Dengan adanya jaringan dalam suatu kelompok pemberdayaan tersebut, memudahkan mereka dalam hal: (1) komunikasi dan sosialisasi program-program kepada antar anggota, (2) memudahkan untuk melaksanakan kegiatan, serta (3) mempertahankan kerukunan antar warga. Dalam hal ini semua program didampingi oleh yayasan dari hulu sampai hilir. Petani tidak perlu repot memikirkan harus dibawa kemana hasil panennya, pasaran harga, serta dapat menghindari tengkulak. Dengan Demikian menunjukkan bahwa sistem jaringan yang dibentuk oleh Yayasan Al Aqsha dalam program pemberdayaan telah membangun kemampuan komponen masyarakat Sumberoto untuk selalu menyatukan diri dalam suatu pola hubungan yang sinergis. Pola jaringan inilah yang sangat besar pengaruhnya dalam memperkuat aspek pendanaan, kemandirian, dan keberlanjutan aktivitas program-program pemberdayaan.

\section{Hubungan Timbal Balik (Resiprocity)}

Fenomena hubungan timbal balik yang didasari semangat membantu orang lain ditemukan dalam beberapa akvitas pelaksanaan pemberdayaan masyarakat miskin yang dilakukan di Desa Sumberoto. Berdasarakan hasil identifikasi dan analisis maka teridentifikasi beberapa aktivitas pemberdayaan yang termasuk resiprocity antara lain: Pertama, muzakki memberikan dana zakat, maka dia akan mendapatkan kepuasan lahirbatin, karena bisa membantu orang lain. Kedua, Yayasan Al-Aqsha memberikan (mengorbankan) segala pemikiran, tenaga, dan waktu, untuk menjalankan program.

Hal yang didapat dari pengorbanan tersebut adalah Yayasan dipercaya sebagai penerima dana zakat yang bisa digunakan untuk merealisasikan program pemberdayaan yang di rintis. Ketiga, Takmir masjid (kelompok pemberdayaan) memberikan pemikiran, tenaga dan waktu untuk mengorganisir masyarakat miskin, sebagai penyuluh/pendamping lapangan mulai proses tanam hingga panen, dan membantu petani memasarkan hasil sawit. Dengan pengorbanan itu, takmir masjid yang perperan sebagai kelompok pemberdayaan akan menerima manfaat dengan semakin makmurnya masjid dan aktivitas dakwah. Keempat, menyisihkan sebagian dari hasil penjualan sawit untuk memakmurkan masjid, dan penguatan kelembagaan dan dakwah masjid, sebagai konsekuensi dari penerima program pemberdayaan ekonomi umat.

Fenomena di Desa Sumberoto, muzaki menyalurkan sebagian hartanya dalam rangka pemberdayaan masyarakat miskin yang ada didesa tersebut, dimana dana program yang dikucurkan berasal dari zakat maal. Dari dana zakat tersebut diharapkan adanya manfaat dunia dan akhirat bagi mereka, kemaslahatan umat, dan yang terpenting terbentuknya suatu perekonomian yang lebih baik bagi rumah tangga miskin yang ada. Sehingga dapat dibuktikan bahwa modal sosial sungguh menghasilkan keuntungan-keuntungan positif yang jelas untuk anggota-anggota jaringan dan komunitas secara luas. Resiprocity yang terjadi di desa Sumberoto telah melahirkan suatu masyarakat yang memiliki tingkat kepedulian sosial yang tinggi, saling membantu dan 
saling memperhatikan. Sehingga, kemiskinan akan lebih memungkinkan atau kemungkinan lebih mudah diatasi.

\section{Bentuk Kepercayaan (Trust)}

Kepercayaan merupakan pengharapan yang muncul dalam sebuah kelompok yang berperilaku normal (tidak menyimpang), jujur, dan kooperatif, yang dibangun berdasarkan norma-norma yang dimiliki bersama, demi kepentingan anggota yang lain dari suatu kelompok. Model pemberdayaan masyarakat miskin yang dibangun di desa Sumberoto didasarkan pada prinsip-prinsip saling percaya terhadap masing-masing unsur pelaku program pemberdayaan. Perilaku kejujuran masing-masing unsur tersebut bisa teridentifikasi sebagai berikut: Pertama, muzakki jujur terhadap kepemilikan dan besarnya nisab zakat yg harus disalurkan. Kedua, Yayasan Al Aqsha amanah (profesionalisme) dan kerja keras dalam menjalanjan program-program yang ditawarkan. Ketiga, ketua kelompok bersungguh-sungguh (benar-benar) mendampingi masyarakat dalam menjalankan program. Keempat, masyarakat berkomitmen untuk menjalankan aturan-aturan yg sudah disepakati dengan ketua kelompok dan yayasan. Kepercayaan (trsust) dalam program pemberdayaan di Desa Sumberoto berperan dalam dua hal yaitu: (1) Masyarakat Sumberoto yang mempunyai kepercayaan yang tinggi (high trust) telah berhasil menciptakan berbagai jaringan dengan baik. (2) Masyarakat Sumberoto yang mempunyai tingkat kepercayaan yang tinggi (high trust societies) terbukti sanggup untuk melakukan kerjasama sampai level organisasi yang sangat besar, semacam korporasi transnasional.

\section{Bentuk Norma Sosial}

Norma merupakan sekumpulan aturan yang diharapkan, dipatuhi dan diikuti oleh anggota masyarakat pada suatu entitas sosial tertentu. Norma-norma ini biasanya terinstitusionalisasi dan mengandung sangsi sosial yang dapat mencegah individu berbuat sesuatu yang menyimpang dari kebiasaan. Model pemberdayaan masyarakat miskin di Desa Sumberoto dibangun dengan norma (norm) atau aturan yang dipatuhi dan diikuti oleh anggota masyarakat dan unsur-unsur pemberdayaan. Norma tersebut antara lain: (a) Yayasan menetapkan aturan: syarat petani yang mendapatkan bantuan program pemberdayaan harus: (i) satu tujuan dengan program yayasan yaitu kemakmuran masjid, (ii) mengikuti sosialisasi melalui pengajian, (iii) mempunyai lahan sendiri; (b) Ketua kolompok, menetapkan aturan: (i) setiap masyarakat yang akan mendapatakan bantuan program harus mengikuti pengajian (jama'ah masjid); (ii) masyarakat harus mengikuti instruksi teknis penanaman sampai panen, (iii) masyarakat harus menjual hasil tanaman sawitnya melalui ketua kelompok, (iv) masyarakat harus menyisihkan sebagian kecil dari hasil penjualan untuk kemakmuran masjid (Rp. 25,setiap $1 \mathrm{Kg}$ TBS); (c) Masyarakat berperan dalam mengawasi aturan-aturan yang sudah disepakati bersama.

\section{Bentuk Nilai-Nilai}

Nilai adalah suatu ide yang telah turun-temurun dianggap benar dan penting oleh anggota kelompok masyarakat. Nilai-nilai yang teridentifikasi dari pelaksanaan program pemberdayaan masyarakat miskin di Desa Sumberoto antara lain: Pertama, Muzakki mempunyai nilai ketakwaan pribadi dan sosial (keperdulian). Kedua, Yayasan mempunyai nilai tanggung jawab, kemauan, dan pengorbanan. Ketiga, Ketua kelompok 
mempunyai nilai kesukarelaan dan kebersamaan. Keempat, Masyarakat mempunyai nilai gotong-ronyong dan kebersamaan mengatasi masalah. Nilai agama senantiasa berperan penting dalam kehidupan sosial masyarakat Sumberoto. Sehingga dari nilai-nilai tersebut memunculkan ide yang berkembang. Kemudian dari ide itulah telah membentuk dan mempengaruhi aturan-aturan bertindak masyarakat (the rules of conduct) program pemberdayaan.

\section{Bentuk Tindakan Proaktif}

Bentuk tindakan proaktif yang ditemukan dalam aktivitas program pemberdayaan masyarakat miskin di Desa Sumberoto antara lain: Pertama, Kegigihan ketua yayasan mulai dari mencari ide, membangun kerja sama, mencari dana, mensosialisasikan program, melatih dan mendampingi masyarakat, serta mendistribusikan hasil kelapa sawit. Kedua, kerja keras ketua kelompok/takmir dalam mengorganisir dan menggerakkan masyarakat. Ketiga, masyarakat saling tukar informasi kesuksesan dan kendala melalui pengajian. Proaktif seluruh komponen program pemberdayaan masyarakat miskin di desa Sumberoto berperan dalam mempercepat pelaksanaan program pemberdayaan, karena mereka senantiasa aktif dan kreatif mencari jalan keluar dalam mengatasi permasalahan. Selain itu proaktif telah melancarkan kesuksesan program karena mereka cenderung tidak menyukai bantuan yang sifatnya dilayani, melainkan lebih banyak melayani secara proaktif.

\section{KESIMPULAN DAN SARAN \\ Kesimpulan}

Berdasarakan hasil analisis terhadap keberadaan modal sosial dalam pemberdayaan masyarakat miskin di Desa Sumberoto, maka diperoleh beberapa kesimpulan, di antaranya; ditemukan adanya sistem jaringan (networking) yaitu hubungan yang saling berdampingan yang dilakukan atas prinsip kesukarelaan (voluntary), kesamaan (equality), kebebasan (freedom) dan keadaban (civility) dalam mekanisme pemberdayaan masyarakat miskin di Desa Sumberoto. Sistem jaringan tersebut terdiri dari unsur: (a) Muzakki atau Lembaga Kesejahteraan Masyarakat Mandiri Pengusaha Lima (LKMP5); (b) Yayasan AL Aqsha; (c) Kelembagaan masjid; (d) Kelompok-kelompok pemberdayaan (takmir masjid); dan (e) Masyarakat (petani) miskin.

Selain itu, ada hubungan timbal balik (resiprocity) dalam mekanisme pemberdayaan masyarakat miskin di Desa Sumberoto, yaitu kecenderungan saling tukar kebaikan antar individu dalam suatu kelompok atau antar kelompok itu sendiri dengan semangat untuk membantu dan mementingkan kepentingan orang lain. Hubungan timbal balik tersebut dapat diidentifikasi dalam aktivitas masing-masing pelaku (unsur) pemberdayaan, sebagai berikut: (a) Muzakki memberikan dana zakat, mendapatkan kepuasan lahirbatin; (b) Yayan $\mathrm{Al}$ aqsha sebagai penerima, bisa merealisasikan program pemberdayaan; (c) Takmir masjid (kelompok pemberdayaan) sebagai penerima, bisa memakmurkan masjid dan dakwah; (d) Masyarakat sebagai penerima, bisa berdaya secara ekonomi; (e) Yayasan Al Aqsha sebagai pemberi, berperan dalam: membuka jaringan, koordinantor pemberdayan, dan pelaksana teknis pemberdayaan; (f) Takmir masjid (kelompok pemberdayaan) sebagai pemberi berperan dalam: mengorganisir masyarakat miskin, penyuluh/pendamping lapangan, dan rantai pemasaran hasil; (g) Masyarakat sebagai pemberi berperan dalam: obyek program pemberdayan, memakmurkan masjid, dan penguatan lekembagaan dan dakwa masjid. 
Model pemberdayaan masyarakat miskin yang ada di Desa Sumberoto dibangun dengan prinsip kepercayaan (trust) yaitu pengharapan yang muncul dalam sebuah komunitas yang berperilaku normal, jujur, dan kooperatif, berdasarkan norma-norma yang dimiliki bersama, demi kepentingan anggota yang lain dari komunitas. Prinsip tersebut tercermin dari sikap masing-masing unsur pemberdayaan berikut ini: (a) Muzakki jujur terhadap kepemilikan dan besarnya nisab zakat yg harus disalurkan; (b) Yayasan Al Aqsha amanah dan kerja keras dalam menjalanjan program-program yang ditawarkan; (c) Ketua kelompok bersungguh-sungguh (benar-benar) mendampingi masyarakat dalam menjalankan program; (d) Masyarakat berkomitmen untuk menjalankan aturan-aturan yang sudah disepakati dengan ketua kelompok dan yayasan.

Model pemberdayaan masyarakat miskin di Desa Sumberoto juga dibangun dengan norma (norm) atau aturan yang dipatuhi dan diikuti oleh anggota masyarakat dan unsurunsur pemberdayaan. Norma tersebut antara lain: (a) Yayasan menetapkan aturan: syarat petani yang mendapatkan bantuan program pemberdayaan harus: (i) satu tujuan dengan program yayasan yaitu kemakmuran masjid, (ii) mengikuti sosialisasi melalui pengajian, (iii) mempunyai lahan sendiri; (b) Ketua kolompok, menetapkan aturan: (i) setiap masyarakat yang akan mendapatakan bantuan program harus mengikuti pengajian (jama'ah masjid); (ii) masyarakat harus mengikuti instruksi teknis penanaman sampai panen, (iii) masyarakat harus menjual hasil tanaman sawitnya melalui ketua kelompok, (iv) masyarakat harus menyisihkan sebagian kecil dari hasil penjualan untuk kemakmuran masjid (Rp. 25,- setiap $1 \mathrm{Kg}$ TBS); (c) Masyarakat berperan dalam mengawasi aturan-aturan yang sudah disepakati bersama.

\section{Saran}

Besarnya peran modal sosial dalam meningkatkan kesejahteraan masyarakat melalui program pemberdayaan masyarakat miskin yang merupakan salah satu temuan penelitian ini, diharapkan akan menjadi inspirasi penentu kebijakan yang selama ini selalu terfokus pada pengembangan modal finansial ataupun fisik dalam rangka meningkatkan kesejahteraan masyarakat miskin. Adanya temuan tentang peran yang lebih nyata dari dana Zakat, Infak, dan Sedekah (ZIS) yang dikelola yayasan sosial dan Kelembagaan Masjid (Takmir) dalam meningkatkan kesejahteraan masyarakat dibanding program-program pemerintah, dapat dijadikan model alternatif untuk mengaplikasikan kosep pengembangan modal sosial yang ada pada lembaga-lembaga lain (NGO) yang fokus pada kegiatan pengentasan kemiskinan.

Temuan bahwa nilai agama seperti ketaqwaan, kejujuran, amanah, merupakan konstruktor terbesar bagi modal sosial, hal tersebut sebaiknya menjadi dasar yang menyemangati bagi pelaksana program-program pengentasan kemiskinan baik yang dilakukan oleh pemerintah atau non pemerintah. Di samping itu, perlu dilakukan penelitian lanjutan dari penelitian ini guna mengkaji secara lebih mendalam dengan pendekatan yang lebih kualitatif terkait temuan-temuan penelitian terutama mengenai dimensi modal sosial apa yang paling berperan terhadap peningkatan kesejahteraan masyarakat miskin. Dengan demikian diharapkan dapat diperoleh aktivitas-aktivitas apa yang mengkonstruksi dimensi tersebut sehingga akan dapat menghasilkan langkahlangkah konkrit kebijakan apa yang harus diimplementasikan. Selain itu, penelitian tersebut juga merupakan langkah triangulasi terhadap penelitian ini. 


\section{DAFTAR RUJUKAN}

Ali, Mohammad Daud. 1988. Sistem Ekonomi Islam: Zakat dan Wakaf. U1-Press. Jakarta

Al-Ba'ly, Abdul Al-Hamid Mahmud. 2006. Ekonomi Zakat: Sebuah KajianMoneter dan Keuangan Syariah. PT. RajaGrafindo Persada. Jakarta Hafidhuddin,

Blakely, Edward J. (1989), Planning Local Economic Development: Theory and Practice, Sage Library of Sosial Research 168, Sage Publikation.

BPS. (1999). Perkembangan Tingkat Kemiskinan dan Beberapa Dimensi Sosial Ekonominya 1996-1999. Jakarta: BPS

Brigaitis, 2005. Religius Engagement and Social Capital in The Islamic Context. Thesis submitted to University of North Texas.

Choi, Hyunsun. 2004. Social Capital and Community Economics Development in Los Angeles Koreatown: Faith-Based Organization in Transitional Etnic Community. Dissertation sudmitted tor University of Southern California.

Ellison , C, and Linda K. George, 1994. Religious Involvement, Social Ties, and Social Support in a Southeatern Community. Journal for the Scientific Study of Relgious 33: 46-61.

Halwani, R. Hendra. 1999. "Paradigma Baru Pembangunan: Pemberdayaan ekonomi Rakyat" Jurnal PSPP. Vol. II. No. 1, 49-64.

Lochart, W, 2005, Building Bringes and Bonds: Generating Social Capital in Secular and Faith-Based Poverty-to-Work Programs, Sociology of Religion, Vol. 66, No. 1 (Spring, 2005),pp 45-60

Multifiah, 2007. Peran ZIS Terhadap Kesejahteraan Rumah Tangga Miskin (Studi Penanggulangan Kemiskinan Melalui Bantuan Moodal, Pendidikan, dan Kesehatan di Daerah Malang). Disertasi, Malang, Universitas Brawijaya.

Piche, E. Religious and Social Capital in Canada. Thesis submitted to Queen's University Canada.

Sahri Muhammad. 2006. Mekanisme Zakat dan Permodalan Masyarakat Miskin: Pengantar Untuk Rekonstruksi Kebijakan Pertumbuhan Ekonomi. Bahtera Press. Malang

Ulin, Priscilla R, Elizabeth T. Robinson, Elizabeth E. Tolley, Erin T. McNeill. 2002. Qualitative Methods; Applied Reseach in Sexual and Reproductive Health. Family Health International. North Carolina. USA. 